\title{
THE ROLE OF MACROPHAGES IN PRIMARY AND SECONDARY INFECTION OF MICE WITH SALMONELLA TYPHIMURIUM
}

\author{
by H. Hof, P. Emmerling, J. Hacker, and C. Hughes \\ Institute of Hygiene and Microbiology, \\ and Institute of Microbiology and Genetics, \\ University of Würzburg, D-87 Würzburg (Fed. Rep. of Germany)
}

\section{SUMMARY}

Elimination of macrophages with high-molecular dextran sulphate (DS) markedly impairs resistance of mice to primary infection with smooth, virulent strains of Salmonella typhimurium, whereas stimulation of this system by killed Bordetella pertussis organisms increases resistance. In infection with rough, avirulent strains of $S$. typhimurium the elimination of macrophages was not followed by an essential loss of resistance, and it appears that other non-specific defence mechanisms, for example the complement system, may have compensated for the lack of macrophages. Macrophages, therefore, play an important role in defence during primary infection with virulent strains.

In immunity to challenge infection with $S$. typhimurium, macrophages play an even more significant role. Treatment with DS completely removes immunity, and both humoral and cell-mediated immune mechanisms seem to require the participation of macrophages.

KEy-words: Macrophage, Salmonella typhimurium; Dextran sulphate, Mouse, $\mathrm{O}$ antigen, Bordetella pertussis.

\section{INTRODUCTION}

Macrophages are of particular importance in the defence against infection by intracellular bacteria such as Listeria monocytogenes [16]. Elimination of these, cells by treatment with a high-molecular weight dextran 
sulphate (DS) strongly impairs the defence system [10], whereas stimulation of macrophage activity by killed Bordetella pertussis cells strengthens host resistance [12].

Virulent strains of Salmonella typhimurium are also said to be facultative intracellular pathogens $[7,24]$, which implies that they could survive and eventually multiply within macrophages. Indeed, after parenteral injection these bacteria are found primarily in the reticulo-endothelial organs such as spleen and liver [21]. Mice with a genetically determined low macrophage activity are more sensitive to Salmonella infection than are those with high macrophage activity [9]. In addition, peritoneal macrophages from resistant mice kill Salmonella more efficiently, in vitro, than those from susceptible animals [18]. Nevertheless, it has been doubted whether in Salmonella infection the macrophages play an indispensable role. During primary infection at least the polymorphonuclear leukocytes rather than the macrophages are prominent in infective foci in spleen and liver of mice [20].

We report here an attempt to further elucidate the role of macrophages during primary infection with $S$. typhimurium by monitoring the course of infection after treatment with either blocking or stimulating agents. In particular, the role of macrophages - and of another non-specific defence mechanism, $i$. $e$. the complement system - in infection with different $\mathrm{O}$-antigen mutants were examined. Such genetically determined alterations [23] of the biochemical composition of the cell envelope [14] considerably influence virulence [22].

In addition, the role of macrophages in immunity to Salmonella reinfection was studied. Immunity to Listeria reinfection is mediated exclusively by cellular mechanisms, whereby the macrophages are the proper effector cells [17]. Without these cells, immunity cannot be expressed [5]. In murine salmonellosis, however, both humoral [13] and cell-mediated [2] mechanisms participate. The role of macrophages in this particular situation is not defined. Although they are implicated according to Nakonezna and Hsu [20], Marecki et al. [19] reported that macrophages of previously infected animals showed no enhanced bactericidal activity.

\section{MATERIALS AND METHODS}

Mice.

Female NMRI mice weighing about 25-30 g were obtained from the Central Institute for Laboratory Animals (Hannover, Fed. Rep. of Germany) in a SPF state. They were held under standard conditions and fed with pellets and water ad libitum.

DS $=$ dextran sulphate

i.p. $=$ intraperitoneally.

i.v. = intravenously. lab. = laboratory.

$\mathrm{PO}=$ pertussis organism.

$\mathrm{SPF}=$ specific pathogen-free. 
TABLE I. - Strains of « S. typhimurium ».

\begin{tabular}{llll} 
Designation & $\begin{array}{c}\text { Running } \\
\text { name }\end{array}$ & Genotype & O-antigen phenotype \\
\hline $1366 / 74$ & lab. & $\begin{array}{l}\text { stres } \\
\text { tetres }\end{array}$ & smooth \\
\hline SF 1397 & LT2 & $s t r^{\text {res }}$ & smooth LT2 \\
\hline SF 1512 & SR & $\begin{array}{l}s t r^{\text {res }} \\
r f c^{-}\end{array}$ & semi-rough form \\
\hline SF 1572 & $\mathrm{Rd}_{1}$ & $\begin{array}{l}s t r^{\text {res }} \\
r f a G^{-}\end{array}$ & rough form $d_{1}$ \\
\hline
\end{tabular}

\footnotetext{
$s t r^{\mathrm{res}}=$ streptomycin-resistant.

tetres $=$ tetracycline-resistant.

$\mathrm{rfc}^{-}=$repeating polymerase-deficient unit.

$r f a G^{-}=$glycosyltransferase-deficient.
}

\section{Bacteria.}

Strains of S. typhimurium are listed in table I. Strains designated SF were obtained from Dr G. Schmidt (Max Planck, Institute for Immunology, Freiburg, Fed. Rep. of Germany). The laboratory (lab.) strain 1366/74 was from the culture collection from the Institute of Hygiene and Microbiology, originally isolated from a stool specimen of a patient with diarrhoea. For infection of mice, fresh cultures of these bacteria were prepared by incubating in tryptose broth for $18 \mathrm{~h}$ at $37^{\circ} \mathrm{C}$.

A suspension of $B$. pertussis organisms (PO; phase I, heat-killed at $56^{\circ} \mathrm{C}$ for $30 \mathrm{~min}$, not absorbed, treated with merthiolate $1 / 10,000$ ) was kindly supplied by Behringwerke (Marburg, Fed. Rep. of Germany). An appropriate suspension containing $10^{9}$ cells per $0.2 \mathrm{ml}$ was injected intraperitoneally (i.p.) into a mouse 7 days prior to infection.

\section{Enumeration of bacteria per spleen.}

Mice were infected intravenously (i.v.) via a tail vein. At intervals after infection animals were killed and the spleens were removed aseptically. After mechanical homogenization in an "Omnimixer " (Sorvall, Newton, USA), duplicate samples of an appropriate dilution were pipetted into plastic Petri dishes and mixed with liquified tryptose agar $(1.5 \%)$. The numbers of colonies were counted after $24 \mathrm{~h}$ at $37 \circ \mathrm{C}$. Mice (4-6) were examined per group and per day; the means and the standard error of the means were calculated.

\section{Transfer of immune cells.}

Mice were immunized by infection with $10^{4}$ cells of the lab. strain of $S$. typhimurium. Four weeks after infection $2 \mathrm{ml}$ of thioglycollate broth were injected i.p. into a mouse. Two days later, cells in the peritoneal cavity were recovered by peritoneal washing with cell culture medium (RPMI-1640 with 20-nmol Hepes buffer, Flow Laboratories, Bonn, Fed. Rep. of Germany) as recommended by Hahn et al. [11]. Cells were washed and counted in a counting chamber. An appropriate suspension of these peritoneal cells was injected i.v. into a recipient mouse together with the bacteria. 


\section{Production of antiserum.}

Rabbits were injected i.v. 8 times every 4 days with 0.5 up to $2 \mathrm{ml}$ of a dense suspension of heat-killed cells of $S$. typhimurium. The agglutination titre in the serum was $1 / 40,000$. A volume of $0.5 \mathrm{ml}$ of this antiserum was injected i. p. into a non-immunized recipient mouse $1 \mathrm{~h}$ before infection.

DS.

DS 500 with a molecular weight of 500,000 was purchased from "Serva Feinbiochemica " (Heidelberg, Fed. Rep. of Germany). One mg of this compound dissolved in $0.2 \mathrm{ml}$ of saline was injected into a mouse $18 \mathrm{~h}$ before infection.

\section{Serum bactericidal assay.}

Serum sensitivity of the various strains of $S$. typhimurium was assessed according to Taylor and Hughes [25]. Fresh normal human serum was obtained from healthy volunteers on the day of the test. Bacteria were grown to midlogarithmic phase, washed and resuspended to about $2-5 \times 10^{6}$ cells $/ \mathrm{ml}$. Bacterial counts were made before and after $2 \mathrm{~h}$ incubating at $37^{\circ} \mathrm{C}$ of a mixture of $0.2 \mathrm{ml}$ of this suspension with $1.8 \mathrm{ml}$ of undiluted serum or of $5 \%$ serum, respectively. Survival is expressed as the percentage of the initial inoculum (mean of 2 independent tests).

\section{RESULTS}

\section{1) Effects of DS on primary infection.}

Only 1 mouse out of 10 died after infection with $5 \times 10^{5}$ cells of the lab. strain of $S$. typhimurium. If $1 \mathrm{mg}$ DS was given 1 day prior to infection, all of the 11 mice died within 8 days (fig. 1).

When infection was performed with a lower dose, i. e. with a non-lethal dose of $10^{4}$ cells of the lab. strain, mice pretreated with DS showed increased numbers of bacteria in their spleen in comparison to normal control animals (data not shown).

Pretreatment with DS was especially deleterious to mice infected with $10^{4}$ cells of the smooth LT2 strain of S. typhimurium. Multiplication was markedly increased in DS-treated animals (fig. 2A). The intermediate variant $\mathrm{SR}$ (fig. $2 \mathrm{~B}$ ) and the rough $\mathrm{Rd}_{1}$ strain (fig. $2 \mathrm{C}$ ) were obviously less virulent, since after infection of mice with $10^{5}$ cells, $i$. e. a dose 10 -fold higher than that given of LT2, lower bacterial counts per spleen were found. In addition, the numbers of these avirulent bacteria in the spleen did not increase but rather steadily decreased with time. This occurred even in the DS-treated mice, although bacterial elimination was somewhat impeded.

2) Effect of DS on actively immunized mice.

Once mice had survived primary infection with $10^{4}$ cells of virulent $S$. typhimurium, they were highly resistant in comparison to non-immune controls to reinfection with $10^{6}$ cells of $S$. typhimurium given 4 weeks 


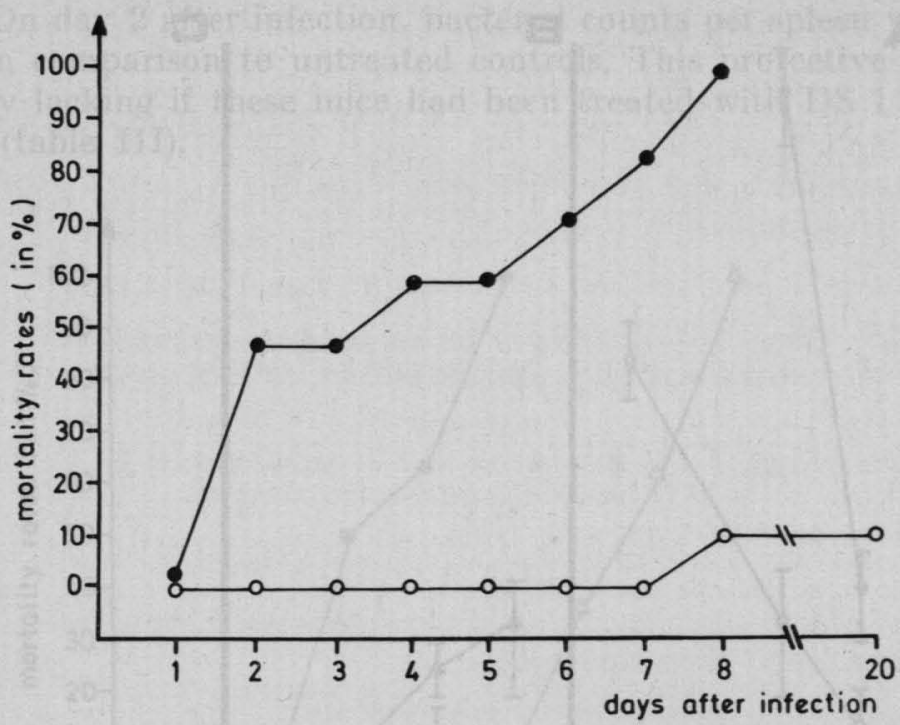

FIG. 1. - Cumulative mortality rates of mice infected

with $5 \times 10^{5}$ cells of a virulent strain of $\mathrm{S}$. typhimurium (lab. strain).

$0=$ control mice; 11 mice were used.

- = mice treated with $1 \mathrm{mg}$ DS on day $-1 ; 10$ mice were used.

later. Such a state of immunity was not only completely suppressed by treatment with DS, given 1 day prior to challenge infection, but mice treated in this way died even more promptly than non-immunized control animals (fig. 3 ).

This finding was substantiated by the enumeration of bacterial counts per spleen. On day 2 of challenge infection with LT2, immunized mice had

TABLE II. - Effect of DS on immunity to challenge infection with LT 2.

Viable counts of

S. typhimurium ${\left({ }^{*}\right)}^{*}$

\begin{tabular}{lr}
\hline Non-primed control mice. & $211,760 \pm 87,000$ \\
\hline $\begin{array}{l}\text { Mice infected with } 10^{4} \text { cells of } S . \text { typhi- } \\
\text { murium } 4 \text { weeks previously }\end{array}$ & $18,6 \pm 3,2$ \\
\hline $\begin{array}{l}\text { Mice infected with } 10^{4} \text { cells of } S . \text { typhi- } \\
\text { murium } 4 \text { weeks previously; } \\
1 \text { mg DS i.p. on day }-1\end{array}$ & $54,570 \pm 35,910$ \\
\hline $\begin{array}{l}\text { Mice infected with } 10^{4} \text { cells of } S . \text { typhi- } \\
\text { murium } 4 \text { weeks previously; }\end{array}$ & $47 \pm 19$ \\
\begin{tabular}{l}
1 mg DS i.p. on day +1 \\
\hline
\end{tabular}
\end{tabular}

(*) Number of $S$. typhimurium in the spleen $\left(\times 10^{2}\right)$ of mice infected 2 days previously with $10^{5}$ cells of $S$. typhimurium (mean and standard error of the mean; 4 mice were used per group). 


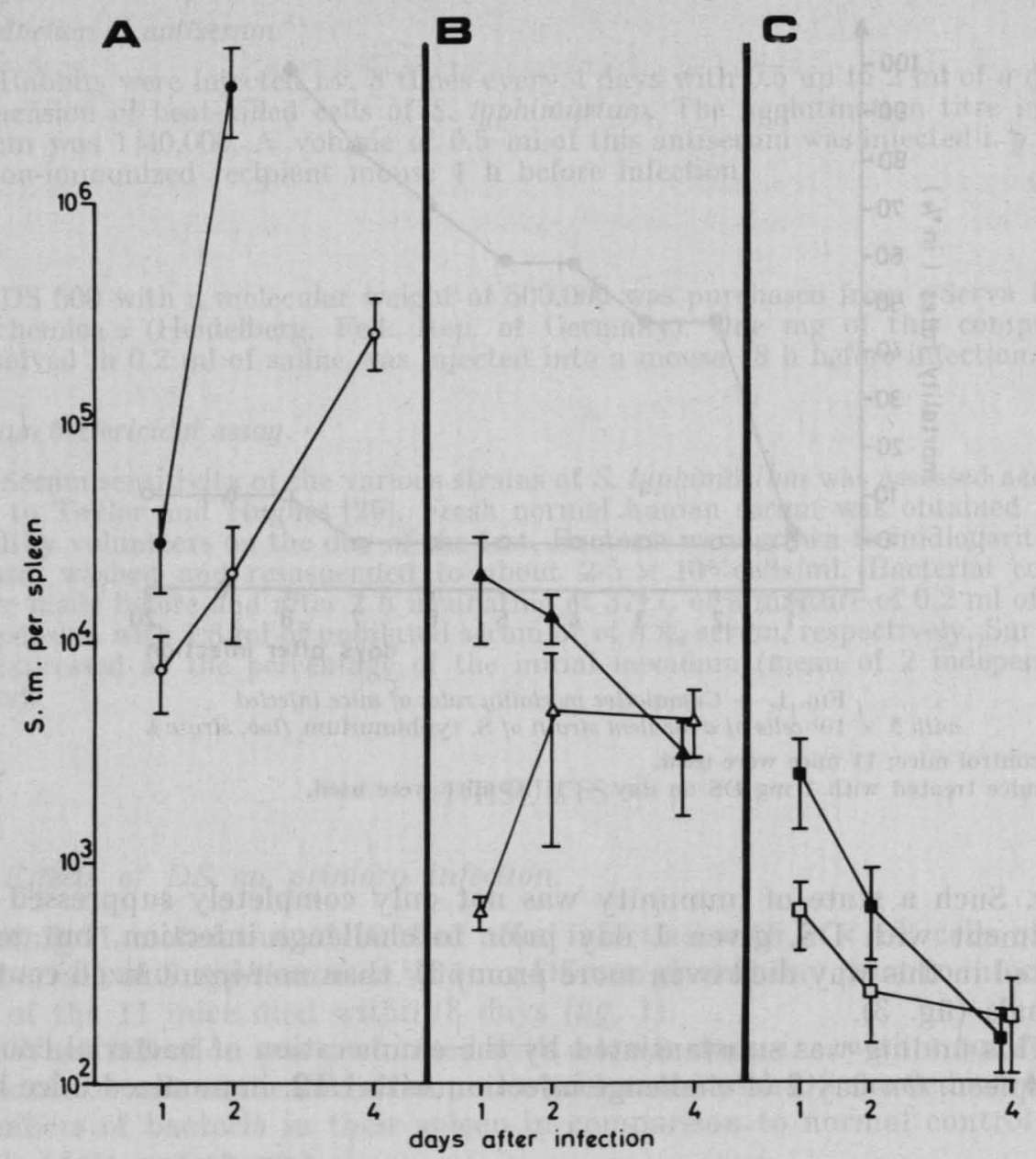

FIG. 2. - Bacterial counts per spleen of infected mice.

$\mathrm{A}=10^{4}$ cells of the strain LT2;

$\mathrm{B}=10^{5}$ cells of the strain $\mathrm{SR}$;

$\mathrm{C}=10^{5}$ cells of the strain $\mathrm{Rd}_{1}$.

$\circ, \Delta, \square=$ control mice;

$\bullet, \mathbf{\Lambda}, \mathbf{m}=$ mice treated with $1 \mathrm{mg}$ DS on day -1 .

considerably lower bacterial counts than non-primed controls. DS-pretreatment removed immunity, since rather high numbers of bacteria are found equivalent to non-primed controls. If DS is given 1 day after challenge infection, there is pratically no more influence on expression of immunity (table II).

3) Effect of DS on animals passively immunized with antiserum.

If mice were passively immunized with specific antiserum, they were partially protected against a low infectious dose of the lab. strain of $S$. typhi- 
murium. On day 2 after infection, bacterial counts per spleen were clearly reduced in comparison to untreated controls. This protective effects was completely lacking if these mice had been treated with DS 1 day before infection (table III).

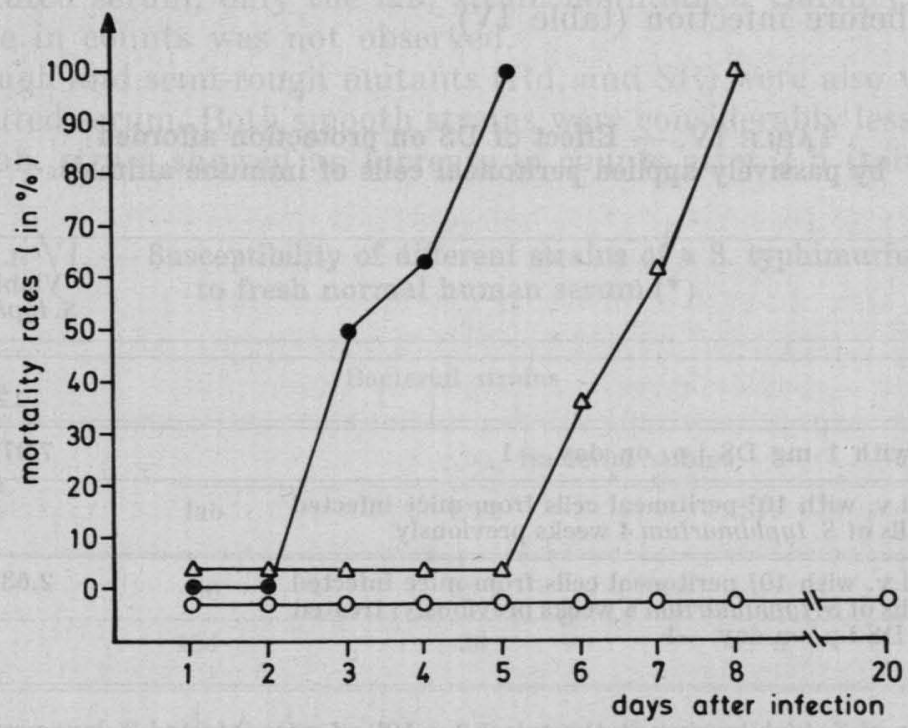

FIG. 3. - Cumulative mortality rates of mice infected with $10^{6}$ cells of the virulent lab. strain of $\mathrm{S}$. typhimurium.

$\Delta=$ control mice;

$\mathrm{O}=$ mice immunized by prior infection with $10^{4}$ cells of $S$. typhimurium;

- = mice immunized by prior infection; treated with $1 \mathrm{mg}$ DS on day -1 before challenge infection (11 mice were used per group).

TABLE III. - Effect of DS on protection afforded by passively applied antiserum.

Viable counts of

S. typhimurium (*)

\begin{tabular}{lc}
\hline Untreated control mice & $28 \pm 13$ \\
\hline Mice treated with $1 \mathrm{mg}$ DS i.p. on day -1 & $875 \pm 247$ \\
\hline $\begin{array}{l}\text { Mice injected i.p. with } 0.5 \mathrm{ml} \text { antiserum } 1 \mathrm{~h} \\
\text { before infection }\end{array}$ & $2 \pm 1$ \\
\hline $\begin{array}{l}\text { Mice treated with } 1 \mathrm{mg} \text { DS i.p. on day }-1 ; \\
\text { injected with } 0.5 \mathrm{ml} \text { of antiserum } 1 \mathrm{~h} \text { before } \\
\text { infection }\end{array}$ & $752 \pm 415$ \\
\hline
\end{tabular}

(*) number of $S$. typhimurium in the spleen $\left(\times 10^{3}\right)$ of mice infected 2 days previously with $10^{3}$ cells of $S$. typhimurium (mean and standard error of the mean; 4 mice were used per group). 
4) Effect of DS on animals passively immunized by cell transfer.

If mice were injected with $10^{z}$ peritoneal cells from immunized donor mice, they were passively protected against infection, at least partially. This effect, however, was no longer seen in recipient animals treated with DS 1 day before infection (table IV).

TABLE IV. - Effect of DS on protection afforded by passively applied peritoneal cells of immune animals.

Viable counts of S. typhimurium (*)

Control mice $128 \pm 58$

Mice treated with $1 \mathrm{mg}$ DS i.p. on day -1 $7,071 \pm 2,918$

Mice injected i.v. with $10^{7}$ peritoneal cells from mice infected with $10^{4}$ cells of $S$. typhimurium 4 weeks previously

$$
5 \pm 1
$$

Mice injected i.v. with $10^{7}$ peritoneal cells from mice infected with $10^{4}$ cells of $S$. typhimurium 4 weeks previously; treated with $1 \mathrm{mg}$ DS i.p. on day -1

(*) Number of $S$. typhimurium in the spleen $\left(\times 10^{3}\right)$ of mice infected 2 days previously with $10^{4}$ cells of $S$. typhimurium (means and standard error of the mean; 4 mice were used per group).

5) Effect of PO on primary infection.

Mice treated with $10^{9} \mathrm{PO}, 7$ days prior to infection with a low dose of the lab. strain of $S$. typhimurium, were more resistant than untreated animals. In the spleens of treated mice a markedly lower number of bacteria was found (table V).

TABLE V. - Effects of PO on primary infection.

\begin{tabular}{lcc} 
& \multicolumn{2}{c}{$\begin{array}{c}\text { Viable counts of } S \text {. typhimurium }\left(^{*}\right) \\
\text { days after infection }\end{array}$} \\
\cline { 2 - 3 } & +4 & +7 \\
\hline ControI mice & $27,600 \pm 11,600$ & $16,600 \pm 1,600$ \\
\hline Mice injected with $10^{9}$ PO i.p. on day -7 & $1,310 \pm 580$ & $1,310 \pm 650$
\end{tabular}

${ }^{*}$ ) Number of $S$. typhimurium in the spleen of mice infected with $10^{3}$ cells of $S$. typhimurium (mean and standard error of the mean; 5 mice were used per group). 
6) In vitro susceptibility of different Salmonella strains to normal serum.

All strains of $S$. typhimurium maintained over $100 \%$ survival when the serum was preheated at $56^{\circ} \mathrm{C}$ for $30 \mathrm{~min}$. But the 4 strains are not equally sensitive to fresh normal human serum. When they were incubated with undiluted serum, only the lab. strain maintained viability, although an increase in counts was not observed.

The rough and semi-rough mutants $\left(R d_{1}\right.$ and $\left.S R\right)$ were also very sensitive to diluted serum. Both smooth strains were considerably less sensitive; only the lab. strain showed an increase in counts after $2 \mathrm{~h}$ (table VI).

\section{TABLE VI. - Susceptibility of different strains of « S. typhimurium » to fresh normal human serum (*).}

Bacterial strains

\begin{tabular}{ccccc}
\hline & \multicolumn{4}{c}{ Bacterial strains } \\
\cline { 2 - 5 } $\begin{array}{c}\text { Concentration } \\
\text { of serum }\end{array}$ & lab & LT2 & SR & Rd $_{1}$ \\
\hline $90 \%$ & 96 & $<2$ & 0 & 0 \\
\hline $5 \%$ & 154 & 38 & $<5$ & 5
\end{tabular}

(*) Percentage of bacteria surviving from $2-5 \times 10^{5}$ cells per $\mathrm{ml}$ inoculum.

\section{DISCUSSION}

The macrophage is said to play an important role in the defence of mice against systemic infection with $S$. typhimurium [4, 9, 21]. Damage of the macrophage system by treatment with DS, which is known to eliminate an essential portion of the macrophage system [10], decreases resistance to infection with virulent strains of $S$. typhimurium. Bacterial multiplication is therefore supported (fig. 2A) and death of the host is promoted (fig. 1). This strongly confirms experiments in which the macrophage system is blocked by silica [8].

Stimulation of the macrophage system by killed Corynebacterium parvum cells increases resistance to Salmonella infection [4]. Equally, killed PO - which have been shown to enhance resistance to Listeria infection via the macrophage system [6] - enhance resistance to infection with S. typhimurium (table V). This finding confirms the results of Andersen [1] which had been contradicted by Collins [4].

These results favour the view that in infection with virulent cells of $S$. typhimurium, which are said to survive and multiply within macrophages [7, 24], the activity of these host cells plays a certain role in the host-parasite relationship.

Since avirulent cells of $S$. typhimurium are more sensitive to killing 
by peritoneal macrophages in culture [7], the lack of macrophages in vivo should lead to an even more prominent defect in resistance. This idea was studied with mutants of $S$. typhimurium possessing different $\mathrm{O}$-antigen composition genetically defined. This part of the outer membrane consists of repeating units, an oligosaccharide chain of varying length, and of an outer core comprising several different sugars [14]. Whereas the smooth LT2 strain has the complete structure, the syngeneic rfc-mutant SR lacks all but one of the repeating units, and the $\mathrm{Rd}_{1}$ mutant has lost all polysaccharide except three heptose molecules [23]. We found the deficient mutants to be clearly less virulent than the complete strain, confirming the work of Roantree [22]. In spite of a higher infective dose, the $\mathrm{Rd}_{1}$ strain was less numerous in the spleen even at day 1 after infection, and the bacterial counts steadily decreased, whereas the cells of the LT2 strain multiplied. The SR strain showed an intermediate response. In mice pretreated with DS and consequently largely depleted of macrophage activity [10], the avirulent bacteria did not persist, whereas multiplication of the LT2 strain was strongly enhanced (fig. 2).

It is concluded therefore that in infection of mice with virulent bacteria, macrophages are involved in resistance but not in infection by avirulent strains of $S$. typhimurium. This finding disproves the suggestion of Valtonen [26] that " phagocytosis by the reticulo-endothelial system is the responsible mechanism for $\mathrm{O}$-antigen-dependent differences in mouse virulence ».

Since the avirulent bacteria are suppressed even in the macrophage depleted host, other defence mechanisms must be responsible. For example the $\mathrm{O}$-antigen-deficient mutants are more sensitive than smooth strains to fresh human serum containing complement (table VI). This is in agreement with earlier data $[3,15]$. It is possible that the complement system could destroy the avirulent bacteria in the absence of macrophages.

During secondary infection, macrophages seem to be indispensable for the expression of immunity since damage of the macrophage system by DS completely removed the state of enforced defence (table II, fig. 3). Apparently the macrophage represents the proper effector cell in immunity to Salmonella infection as is the case in infection with other intracellular pathogens such as $L$. monocytogenes $[5,17]$.

In contrast to Listeria infection, immunity to Salmonella infection is not only mediated by cellular [2] but also by humoral [13] mechanisms. Both humoral (table III) and cellular (table IV) immunity do require the macrophage as effector cell. Antiserum, said to afford a certain degree of protection [13] which is confirmed here (table III), is apparently unable to exert its beneficial action without the aid of an active macrophage system. Hence, when the macrophages are paralysed by DS, antiserum is no more effective. The transfer of immunity by peritoneal cells from immunized animals resulted in an increased resistance to infection [27]. This effect was destroyed by treatment with DS (table IV).

In conclusion, macrophages appear to play an important role in infection with $S$. typhimurium, and only during infection with avirulent strains may these cells be replaced by other defence mechanisms. 


\section{RÉSUMÉ}

\section{LE RÔLE DES MACROPHAGES}

AU COURS DE L'INFECTION PRIMAIRE OU SECONDAIRE DE LA SOURIS aVec "SAlmonella typhimurium "

L'élimination des macrophages par le sulfate de dextrane (SD) de poids moléculaire élevé entraîne une réduction de la résistance de la souris à une infection primaire avec des souches "smooth" virulentes de Salmonella typhimurium. Par contre, la stimulation du système macrophagique par des cellules tuées de Bordetella pertussis entraîne une augmentation de la résistance. Dans l'infection avec des souches "rough" avirulentes de S. typhimurium, l'élimination des macrophages n'est pas suivie d'une perte considérable de la résistance. Il semble, au contraire, que d'autres mécanismes de résistance non spécifiques - l'intervention du complément, par exemple - puissent compenser chez la souris le déficit de la fonction macrophagique. Si donc les macrophages jouent un rôle important tout particulièrement lors de l'infection avec des souches virulentes de $S$. typhimurium, leur rôle au cours d'une infection secondaire semble encore plus déterminant puisque l'administration de SD à la souris immunisée supprime complètement son état d'immunité. Ainsi la participation des macrophages est essentielle, aussi bien pour l'immunité humorale que pour l'immunité cellulaire envers $S$. typhimurium : les macrophages sont les cellules effectrices indispensables à l'acquisition de cette immunité.

Mots-CLÉs : Macrophage, Salmonella typhimurium; Sulfate de dextrane, Souris, Antigène $\mathrm{O}$, Bordetella pertussis.

\section{REFERENCES}

[1] Andersen, E. K., Studies on reproducibility in determining a decline in protection during immunization against $H$. pertussis infection, and on the effect of pertussis immunization on the resistance of mice to heterologous infection. Acta path. microbiol. scand., 1957, 40, 235-247.

[2] Blanden, R. V., Mackaness, G. B. \& Collins, F. M., Mechanisms of acquired resistance in mouse typhoid. J. exp. Med., 1966, 124, 585-600.

[3] Clas, F. \& Loos, M., Killing of the S and Re forms of Salmonella minnesola via the classical pathway of complement activation in guinea-pig and human sera. Immunology, 1980, 40, 547-556.

[4] Collins, F. M., Vaccines and cell-mediated immunity. Bact. Rev., 1974, 38, 371-402.

[5] Emmerling, P., Finger, H. \& Hof, H., Cell-mediated resistance to infection with Listeria monocytogenes in nude mice. Infect. Immun., 1977, 15, 382385.

[6] Finger, H., Heymer, B., Wirsing, C.-H., Emmerling, P. \& Hof, H., Reversion of dextran sulphate-induced loss of antibacterial resistance by Bordetella pertussis. Infect. Immun., 1978, 19, 950-960.

[7] Friedberg, D. \& Shimo, M., Role of cell wall structure of Salmonella in the interaction with phagocytes. Infect. Immun., 1970, 2, 279-285. 
[8] Friedman, R. L. \& Moon, R. J., Hepatic clearance of Salmonella typhimurium in silica-treated mice. Infect. Immun., 1977, 16, 1005-1012.

[9] Gröschel, D., Paas, C. M. S. \& Rosenberg, B. S., Inherited resistance and mouse typhoid. - I. Some factors which affect the survival of infected mice. J. reticuloendoth. Soc., 1970, 7, 484-499.

[10] Hahn, H., Effects of dextran sulphate 500 on cell-mediated resistance to infection with Listeria monocytogenes in mice. Infect. Immun., 1974, 10, 1105-1109.

[11] Hahn, H., Kaufmann, S. H. E., Miller, T. E. \& Mackaness, G. B., Peritoneal exsudate T lymphocytes with specificity to sheep red blood cells. - I. Production and characterization as to function and phenotype. Immunology, 1979, 36, 691-698.

[12] Hof, H., Emmerling, P., Finger, H. \& Wirsing, C.-H., Einfluss von abgetöteten Zellen von Bordetella pertussis auf die Infektabwehr gegen Listeria monocytogenes. Zbl. Bakt., I. Abt. Orig., 1978, 240, 208-214.

[13] Jenkin, C. R. \& Rowley, D., Basis for immunity to typhoid in mice, and the question of " cellular immunity ». Bact. Rev., 1963, 27, 391-404.

[14] Lüneritz, O., Westphal, O., Staub, A. M. \& Nikaido, H., Isolation and chemical and immunological characterization of bacterial lipopolysaccharides, in "Microbial toxins" (Vol. IV). Bacterial endotoxins. (G. Weinbaum, S. Kadis \& S. J. Ajl), (pp. 145-233). Academic Press, New York, 1971.

[15] Lyman, M.-B., Steward, J. P. \& Roantree, R. J., Characterization of virulence and antigenic structure of Salmonella typhimurium strains with lipopolysaccharide core defects. Infect. Immun., 1976, 13, 1539-1542.

[16] Mackaness, G. B., Cellular resistance to infection. J. exp. Med., 1962, 116, 381-406.

[17] Mackaness, G. B., The influence of immunologically committed lymphoid cells on macrophage activity in vivo. J. exp. Med., 1969, 129, 973-992.

[18] Maier, T. \& Oels, H. C., Role of the macrophage in natural resistance to salmonellosis in mice. Infect. Immun., $1972,6,438-443$.

[19] Marecki, N. M., Hsu, H. S. \& Mayo, D. R., Cellular and humoral aspects of host resistance in murine salmonellosis. Brit. J. exp. Path., 1975, 56, 231-243.

[20] Nakonezna, J. \& Hsu, H. S., The comparative histopathology of primary and secondary lesions in murine salmonellosis. Brit. J. exp. Path., 1980, 61, 76-84.

[21] Orskov, J., Jensen, K. A. \& Kobayashi, K., Studien über Breslauinfektionen der Mäuse, speziell mit Rücksicht auf die Bedeutung des Reticuloendothelgewebes. Z. Immun.-Forsch., 1928, 55, 34-68.

[22] Roantree, R. J., The relationship of lipopolysaccharide structure to bacterial virulence, in " Microbial toxins " (Vol. V). Bacterial endotoxins. (S. Kadis, G. Weinbaum \& S. J. Ajl), (pp. 1-32). Academic Press, New York, 1972.

[23] Stocker, B. A. D. \& Mäkelä, P. H., Genetic aspects of biosynthesis and structure of Salmonella lipopolysaccharide, in "Microbial toxins " (Vol. IV). Bacterial endotoxins (G. Weinbaum, S. Kadis \& S. J. Ajl), (pp. 369-438). Academic Press, New York, 1971.

[24] Suter, E. \& Ramseier, H., Cellular reactions in infection. Advanc. Immunol., $1964,4,117-173$.

[25] Taylor, P. W. \& Hughes, C., Plasmid carriage and the serum sensitivity of enterobacteria. Infect. Immun., 1979, 22, 10-17.

[26] Valtonen, M. V., Role of phagocytosis in mouse virulence of Salmonella typhimurium recombinants with $\mathrm{O}$ antigen 6,7 or 4 , 12. Infect. Immun., $1977,18,574-582$.

[27] Vennemann, M. B. \& Berry, L. J., Cell-mediated resistance induced with immunogenic preparations of Salmonella typhimurium. Infect. Immun., $1971,4,381-387$. 


\title{
PROPRIÉTÉS
}

\section{ANTITUMORALES CYTOSTATIQUES ET CYTOTOXIQUES DES GELLULES PÉRITONÉALES \\ DE SOURIS CONVENTIONNELLES \\ ET AXÉNIQUES STIMULÉES OU NON PAR CORYNEBACTERIUM PARVUM}

\author{
par A. Fray $\left({ }^{1}\right)\left({ }^{*}\right)$. C. Moreau $\left({ }^{2}\right)$, N. Thobie $\left({ }^{(}\right)$et $\mathbf{R}$. Ducluzeau $\left({ }^{2}\right)$ \\ (') Institut d'Immuno-Biologie (INSERM) U.20, CNRS-LA.143), \\ Hôpital Broussais, 75674 Paris Cedex 14, et \\ (2) Centre National de Recherches Zootechniques, \\ 78350 Jouy-en-Josas (France)
}

\begin{abstract}
SUMMARY
ANTI-TUMOUR Cytostatic AND CYTOTOXIC PROPERTIES

OF PERITONEAL EXUDATE CELLS OF CONVENTIONAL

AND GERM-FREE MICE, STIMULATED OR NOT By "Corynebacterium parvum»
\end{abstract}

The treatment by Corynebacterium parvum induced an increase of peritoneal cell number in conventional mice but no modifications in germfree mice. Against YC8 tumoral target cells, cytostatic properties of peritoneal cells were of the same intensity in conventional and germ-free after $C$. parvum treatment. Against K.BALB cells, C. parvum treatment induced an increase of cytostatic properties from 9 to $93 \%$ in conventional mice and from 51 to $84 \%$ in germ-free mice. Cytotoxic properties were increased by $C$. parvum in conventional mice but were inchanged in germ-free mice. The bacterial flore could play a role in the cytotoxic and cytostatic properties of peritoneal cells in conventional mice.

KEY-words: Tumour, Corynebacterium parvum, Immunoregulation, Peritoneal cell; Conventional and germ-free mice, Cytostasis, Cytotoxicity.

Manuscrit reçu le 15 avril 1981, accepté le 29 décembre 1981.

(*) Nouvelle adresse : INSERM-U.203, Laboratoire de Pathologie Expérimentale,' Faculté Necker-Enfants-Malades, 75730 Paris Cedex 15.

Ann. Immunol. (Inst. Past.), 133 C, $\mathrm{n}^{\circ} 1,1982$. 